\section{TRADE NOTES.}

\section{BRI'TISH.}

Nigeria in 1917.-The total vinlue of the exports from Nigeria in 1917, exclusive of specie, was $£ 8,602,486$, and was higher than in any previous year in the history of the colony. The exports included rubbor $(878,281$ lb.), tin ore $(9,966$ tons), palm oil ( 74,619 tons), palm kernels ( 185,998 tons), and ground nuts (50,334 tons).

Sixty-six tin mining companies continued operations during the year, their nominal capital being $\mathcal{L}_{5}, 717,107$ and their working capital \&2,678,858. (iold mining operations were continued near Mlimna, in the Niger Province, and 2,\{305.7 oz. of gold, all alluvial, was won. 'The general dovolopment of tho Udi Colliery has been very rapid, 83,405 tons of coal being mined.

The Director of Agriculture reported that great developments aro possible in the cultivation of maize, cotton and groundnuts; maize and groundnut seed were distributed as an initial step towards tho end of the year.

'Tho season was a fitir one for most crops except cotton, which was a serious failure. With the excoption of groundnuts and palm produce, crops for oxport were restricted by the shortage of shipning tacilities.

'The rubber market was not active, but satisfactory prices were obtained. The mothods of getting tho rubber are wisteful, and the industry is barely prolitable. Rubber tapping was again carried out at the Government ngricultural stations at Calabar and Agege Para with a viow to thimning out these plantations. 'The cultivation of the sugar cane makes progress on nativo plantations, approximatoly 150 acres being under cultivation.-(Col. Rep.-Aun., No. 1008, Nov., 1919.)

Ashanti in 1918.- - Wxports from Ashanti in 1918 wero valued at $f 1,292,730$ as compared with $£ 1,378,706$ in 1917, and included gold (£421,736) cocoa $(£ 360,000)$, koli $(£ 360,000)$, rubber $(£ 36,000)$ and hides and skius $(£ 20,000)$. Trade in genera decreased owing to low prices ocensioned by a lack of shipping facilities and by war restrictions. Tho price of rubber was disappointing, the niarkot doclining stoadily throughout the your. Tho amount of gold produced during tho year was $99,278.85$ oz., valued at $\$ 421,736$, as compured with $116,456.30$ oz., valued nt $£ 494,70614 \mathrm{~s}$., in 1917 . (Col. Rep.-Ann., N'o. 1012, Dec., 1919.)

\section{IOORISIGN.}

Calcium Carbide Importution into China.-Tho Canadian Government 'Irade Commissionor at Shanghai states that the importation of calcium carbido into China is probably nbout 300 tons per annum, somo 250 tons of this being imported by one firm for use in aeotylene-gns welding. Scarcoly any calcium carbido is used for lighting purpose in China.-(Bull. Dept. I'rade and Comm., Canada, Dea. 20, 1919.)

Graphite Situation in Madagascar.-The domand for rraphito has decreased considorably, and most of tho small mines havo been compelled to shut down. Tho lnrgor undortakings aro working on a reduced scale, and in order to meet present compotition aro producing higher grade maturial. Tho averago grado produced in 1017 wus 80-82 per cent. carbon; to-day considerable quantitics of 00 per cont., and ovon higher, material aro boing marketed. It is ostimated that tho 1019 production will bo about 6,000 tons, whilo a rolinblo authority places tho total stocks in the country at 25,000 tons. The avorago prico in July was 550 francs por motrio ton for 90 per cont. quality. Tho prospects a ro not at all favourablo, as tho largest buyer of MIudnyascar flako has rocontly cancelled its contrasts. (U.S. Com. IRep., N'ov. 21, 1010.)

\section{OBITUARY.}

CHARLES EDWAIRD GROVES.

By the death of Mr. C. D. Groves this Society loses otlo of its originnl members. Groves was born at Highgate in 1841, and was educated at Brixton College and under Hofmann at tho Royal College of Chemistry. lior many years he was lecturer in Chemistry at Guy's Hospital, retiring in 1901. Ho took an activo part in founding tho Instituto of Chemistry, wis secretary thereof until 1892, and vice-president from 1892 to 1895 . 'T'wice he served on tho council of the Chemical Society, once as vice-president, and was elitor of the Journal from 188.1 to 1899 . Ho also elited Calvert's "Dyeing and Calico Printing, two solumes of Chemical 'Technology, two volumes of Mliller's Chemistry, and two rolumes of Iresenius's Analysis. In these capacities his knowledge of several lunguages stood him in good stend.

Most of his resenrch work was carried out in conjunction with Dr. J. Stenhouso, and dealt with organic substances; naphthol, orcinol, gardenin, berberine, erythrin, rocellinin, and Icacin all engaged his attention. Ho exhibited specimens of original substances at the Pranco-British Exhibition in 1908. Chemists owe much to Groves for his introduction of what is now an indispensable article in every laborntory, the indiurubber cork; he also originated the olass Liebig condenser. He gained his F.R.S. in 1883, and was a regular attendant at the meotings as well as at those of other scientific societies. Ho was consulting chemist to the Thames Conservancy for over twenty years, retiring in 1009 . For a fow years longer ho was ablo to maintain his interest in scientific work and progress, but failing health finally necessituted completo rotiroment, and he died on February 1, at his home at Kennington. Apart from his technical attainments, Alr. Groves was a man of marked literary ability and great personal charm.

Huhuent F. Stejhengon.

With deep regret wo record the death, on Fobruary 17, of Prof. J. Emerson Reynolds, who Borved as president of this Socicty in 1891-1802.

\section{REVIEW.}

Ioxs, Electhons, and Ionibing Ramiations. By J. A. Crowtukn. P'p. vi.t270. (London: Eduard Armold. 1919.) Price 12s. 6d. net.

Tho older philosophy taught that an impassablo gulf was fixed between the realm of physics and that of chomistry. A physical chango was defined in tho text-books of soms twenty years ago as a change in which tho moleculo of tho sulwtances involved remained intact. In contradistinction, any chango accompanied by the production of now atomic groupings wns described as a chomical chango. Modern philosophy tenches that physics and chemistry mergo inta ono another, tho gulf previously assumed to exist boing bridged by the recognition of physical chemistry as $n$ transition subject. The roviower would go furthor and contend ihat chemistry and physics nre ono and indivisiblo. Physical chemistry is not a kind of "No man's land" but ratlier an "Fveryman's land"-to chomist and physicist impartinlly. Tho work under roviow illustrates this contontion. Physicnl chemistry, as taught to chemists, is gonorally rogarded as possessing a chomical bias. Novortheless, tho tranformations mninly considored in such troatmont nre such as involve. no destruotion of the molecnlo. The nower physical chemistry-that of tho electron-wonld, wo think, bo rogarded as 
physical chemistry with a physical bias; but, curiously, it is concerned entirely with atomic and sub-atomic disintegrations.

'The work under review is offered by the author as an attempt to supply tho student entering upon the study of the "new Physies," with " the same help and guidance which is alrendy provided for him in other branches of physics by numerous textbooks, clementary and advanced." The work is not intended to bo either a "popular" exposition of the matter nor a compendious synopsis of tho wholo subject. 'The author's provious book, "Molecular Physics," and his distinguished contributions to the growth of the subject, afford sufficient guarantec of his ability to undertnko the task. It ean at once be said that the author has succeded to a very considerable degree in presenting a concise and clear account of tho diverse phenomena contained in the classic works on the subject. 'The text embraces sixteen chapters, and among the subjects treated are tho phenomena nttendant upon the passage of a current through an ionised gas, the clarncteristic properties of the gaseous ions, ionisation by collision, cathode, positive and X-rays, photo-electricity, radio-actire changes, the electron theory of matter and allied subjects. The author starts out with the laudablo intention of cmphasising the underlying physical priuciples at the expense of mathematical treatment of the subject, wherover possible. In spite of this intention, tho reviewer is loft with the impression that the uscfulness of the work would bo very considerably extended if it were found possible to curtail further tho inathematical treatment, ndditional experimental detnils being substituted therefor.

A careful perusnl of tho work tempts the writer to offer the following as amongst a number of minor points which should receivo attention when the issue of a second edition of the work is being considered. It is incorrect to state, as on pago 4 , "the ions were thus rendered risible ..." The render is left with the impression that tho ions themselves aro inade visible. On pago 10 , lino 11 , the current should bo $3.3 \times 10^{-15}$ amperes, and not $3.3 \times 10^{-16}$ amperes as given. On tho snme page, equation (1) should resd $i=-\frac{a Q}{d} t=-C_{d}^{d}$, the minus sign is of no little importance in another connexion. Tho introduction of $\lambda$ on page 10 is $a$ little obscuring, as subsecfuently in the paragraph it is not used. Incidentally, it may be remarked that this symbol $\lambda$ is used in the work with the separate significance of mean freo path, wave length and co-allicient of absorption-a literal Pooh Bah ! There nppears to be some confusion of the symbols $v$ and $v^{2}$ in $\S 12$. "Jo speak of "complicated constants," as on page 22, tempts ono to enquiro what a constant really is. Tho roproductions of Wilson's plotograplis-Figs. 17 and 18-could bo considernbly improved. Occasionnl use is made of the expression "sign of the point" as on pago 70 , when what is meant is the sign of the chargo on the point. Fig. 02 would bo improved by drawing in tho ro flected wavo front. It is distinctly mislending to speak, as on pago 158, of the crystal diffraction structure as the exnet analogno of the ordinary diffraction grating. The contrast botweon tho two is clearly seen from the fact that no path difference is introduced in the case of regulnr roflection from the orlinary diffraction grating. Among a number of minor points, wo consider that the numerous graphs illustrating tho texts would bo improved if tho significance and the scales of ordinates and abscissne wero inserted in overy cnso. Referenco might also bo made to the various sources whence further dotails of the various resoarches inight bo dorived. The concluding parngraph of tho toxt lenves ono with the impression that the development of tho subject waits upon the further dovelopment of the quantum hypothesis boforo the prin- ciples of the subject can be definitely laid down. In the reviewer's opinion this is not so. The fundamental principles can be, and indeed havo been, stated in Schott's " Jilectromagnetic IRadintion," without reference either to the quantum liypothesis or the now "popular" Postulate of Relativity, Parenthotically it may bo remarked that it appears that a strict application of the Postulato of Relativity excludes tho possibility of a mechanical explanation of the electron.

Wherein consists tho importnnco of the subject to the industrial chemist? Principally, though not entirely, in the matter of future supplies of energy. However well the New York striker's reply to the query as to tho strikers' reruirements, "I don't know what wo want, but wo want it mighty bad and we want it mighty quick," may epitomiso things generully at present. the immediato and insistent demands of industrial chemistry can be stated with no little precision. Chemical industry needs an abundant and consequently cheap supply of rendily available energy. Atomic cnorgy is certninly abundant. Tho total heat emitted from ono gram. of radium cmanation (sco page 249 ) is $2.41 \times 10^{2}$ calories. Contrast with this the $3.8 \times 10^{3}$ calories of heat liberated in the formation of one gram of water from its clements-the most energetic cliemical reaction known. There aro some-Sir Oliver Todge is among the prophets-who visunliso a not very distant futuro when atomic energy will bo arailable for the everyday purposes of industry. Othors regard the tapping of these nlmost inexhaustiblo supplies as about as probalble ns the importation of conl from the moon. The futuro holds the solution. It can only be said that progress is being made, and that possibly wo are on the threshold of big discoveries. Chemicnl technologists need to be abrenst of these possibilities, and the present work is lienrtily recommended to such as possess the necessary morlicum of mathematical training. J. S. G. Tromas.

\section{PUBLICATIONS RECEIVED.}

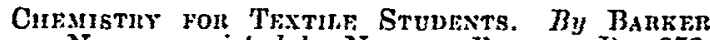
Nontu, assisted by Nomsas Bi.axn. l'p. 379. Cambridge Technical Series. (Gambridge: The University Press. 1920.) I'rice 30s.

A Text-Book of Quantitative Axaryse. By A. C. Cumsuse and S, d. Kay. Thind edition, revised and enlarged. P'p. 410. (Iondon: Gurney and Jackson. 1020.) Price 12s. Gd.

TuE MrNemangy of THE R.tmete Metates, By. Cumes and W. O. Wootrox. Second edition, revised by F. Canen. 1'p. 240. (London: C. Griffin and Co, 1920.) P'rice 10s. Gd.

Pundications of thif United Stites Bunfau of Mines. Deraiturest on tme INTEmor. (Washington: (iovernment Printing Ofice. 1919.)

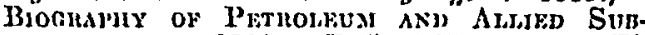
RTaxces in 1816. Bull. $105 . B_{y} \mathrm{E}$. H. Bunnougis.

Rrcoveky of ZiNo punat Jow Gunpa and Conprixx Ones. Bull. 168. By 1). $\Lambda$. LYoN and O. C'. Ralston.

Indinois Mlinino Statites Annotated. Bull. 160. B!y J. W. 'l'mosursos.

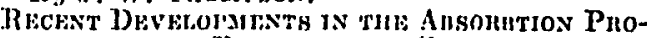

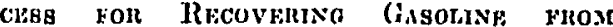
Natumat Gas. Bull. 176. By W. D), Dyknas.

Tirs Dichine and Uetiante Propuct of Oir WedLs: with Notes on the Valuation of Oil Properties. 73ull. 177. By C. H. Bridt.

Pretholikubl Investiantiona and Ploduction of Hrimuat, By van H. Mlannina.

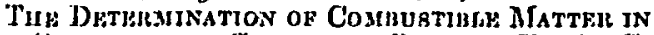

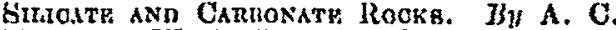
Finiduner, W. $\Lambda$. Skivio and G. B. TAYLon. 